\title{
Fungal/bacterial ratios in grasslands with contrasting nitrogen management
}

\author{
Franciska T. de Vries ${ }^{\mathrm{a}, \mathrm{b}, *}$, Ellis Hoffland ${ }^{\mathrm{a}}$, Nick van Eekeren ${ }^{\mathrm{c}}$, \\ Lijbert Brussaard $^{\mathrm{a}}$, Jaap Bloem ${ }^{\mathrm{b}}$ \\ ${ }^{a}$ Wageningen University and Research Centre, Department of Soil Quality, P.O. Box 8005, NL-6700 EC Wageningen, The Netherlands \\ ${ }^{\mathrm{b}}$ Wageningen University and Research Centre, Alterra, Soil Sciences Centre, P.O. Box 47, NL-6700 AA Wageningen, The Netherlands \\ ${ }^{\mathrm{c}}$ Louis Bolk Institute, Department of Organic Agriculture, Hoofdstraat 24, NL-3972 LA Driebergen, The Netherlands
}

Received 8 September 2005; received in revised form 7 December 2005; accepted 10 January 2006

Available online 20 March 2006

\begin{abstract}
It is frequently hypothesised that high soil fungal/bacterial ratios are indicative for more sustainable agricultural systems. Increased $F / B$ ratios have been reported in extensively managed grasslands. To determine the shifts in fungal/bacterial biomass ratio as influenced by grassland management and to find relations with nitrogen leaching potential, we sampled a two-year-old field experiment at an organic experimental farm in the eastern part of The Netherlands. The effect of crop (grass and grass-clover), $\mathrm{N}$ application rate $(0,40$, $80,120 \mathrm{~kg} \mathrm{~N} \mathrm{ha}^{-1}$ ) and manure type (no manure, farm yard manure and slurry) on the $F / B$ ratio within three growing seasons was tested, as well as relations with soil and crop characteristics, nitrate leaching and partial $\mathrm{N}$ balance. Biomass of fungi and bacteria was calculated after direct counts using epifluorescence microscopy. Fungal and bacterial biomass and the $F / B$ ratio were higher in grass than in grassclover. The $F / B$ ratio decreased with increasing $\mathrm{N}$ application rate and multiple regression analysis revealed a negative relationship with $\mathrm{pH}$. Bacterial activity (measured as incorporation of $\left[{ }^{3} \mathrm{H}\right]$ thymidine and $\left[{ }^{14} \mathrm{C}\right]$ leucine into bacterial DNA and proteins) showed the exact opposite: an increase with $\mathrm{N}$ application rate and $\mathrm{pH}$. Leaching increased with $\mathrm{N}$ application rate and was higher in grass-clover than in grass. Partial $\mathrm{N}$ balance was more positive at a higher $\mathrm{N}$ application rate and showed an inverse relationship with fungal biomass and $F / B$ ratio. We conclude that the fungal/bacterial biomass ratio quickly responded to changes in management. Grasslands with higher $\mathrm{N}$ input showed lower $F / B$ ratios. Grass-clover had a smaller fungal biomass and higher $\mathrm{N}$ leaching than grass. In general, a higher fungal biomass indicated a lower nitrogen leaching and a more negative partial $\mathrm{N}$ balance (or smaller $\mathrm{N}$ surplus), but more observations are needed to confirm the relationship between $F / B$ ratio and sustainability.
\end{abstract}

(C) 2006 Elsevier Ltd. All rights reserved.

Keywords: Grassland; Microbial biomass; Fungi; Bacteria; Management; Nitrogen; Leaching; Clover

\section{Introduction}

Organic matter plays a key role in many soil processes because it affects, among others, soil structure, nutrient dynamics and soil life. Decomposition of soil organic matter is a highly important process. The rate of decomposition depends on environmental conditions (e.g. temperature, moisture conditions), on the quality (e.g. C/N ratio) of the substrate and on the characteristics of the

\footnotetext{
${ }^{*}$ Corresponding author. Tel.: +31317485510 ; fax +31317483766 .

E-mail address: Franciska.devries@wur.nl (F.T. de Vries).
}

decomposing organisms and their predators (i.e. $\mathrm{C} / \mathrm{N}$ ratio, growth efficiency) (Bloem et al., 1997; Swift et al., 1979).

The main decomposition pathways in soil are either bacterial-based or fungal-based. Both bacteria and fungi support their own chain of soil fauna (De Ruiter et al., 1993; Wardle and Lavelle, 1997). Therefore, the biomass of fungi compared to bacteria can be considered as an indicator for the activity of two pathways of the soil food web, formed by fungivores or bacterivores and their predators, respectively.

Generally, fungal biomass is found to be greater than bacterial biomass in agricultural soils (Anderson and Domsch, 1975; Sakamoto and Oba, 1994; Schnurer et al., 
1986; Zelles et al., 1995). In The Netherlands, however, analyses of soil samples from conventionally managed arable as well as grassland soils have shown that the soil microbial biomass is usually strongly dominated by bacteria (Bloem et al., 1994; Hassink et al., 1993; Velvis, 1997). Less than $20 \%$ of the soil microbial biomass in these soils consists of fungi. Consequently, the soil fauna is dominated by bacterivores and their predators (De Ruiter et al., 1993). Recent analyses of more extensively managed Dutch grasslands show a much higher contribution of fungi to the microbial biomass (50-80\%) (Bloem et al., 2004).

Increased fungal/bacterial $(F / B)$ biomass ratios in extensively managed grasslands are consistent with recent other reports (Bailey et al., 2002; Bardgett and McAlister, 1999; Donnison et al., 2000; Grayston et al., 2001; Zeller et al., 2001). The mechanisms responsible for shifts in the soil microbial community remain largely unknown. Some studies have shown that on arable land soil management affects the $F / B$ biomass ratio (Beare et al., 1997; Frey et al., 1999). In most cases bacteria dominate under conventional tillage, whereas fungi dominate under notillage. This has been attributed to a direct contact between bacteria and substrate under conventional tillage, encouraging bacterial growth (Beare et al., 1997). Also, mycelial networks are destroyed by tillage. The effect of "tillage" (cultivation or slit injection of slurry) on fungal/bacterial biomass ratios in grasslands has not been investigated. Grazing has been reported to have either a positive (Bardgett et al., 1997) or a negative impact (Ghani et al., 2003 ) on the $F / B$ ratio. Shifts in the $F / B$ ratio related to grassland management have so far been attributed to quantity (Mawdsley and Bardgett, 1997) and quality (Grayston et al., 2001) of root exudates, changes in quality and quantity of litter or input of animal faeces (Bardgett et al., 1996) and plant productivity and composition (Donnison et al., 2000). $F / B$ ratios may also be affected by other factors, e.g. toxic metals (Tobor-Kaplon et al., 2005). Most of these factors are related to nutrient availability. Bittman et al. (2005) found a decreasing fungal biomass as a consequence of application of manure and fertiliser. Inorganic nitrogen fertilisation has been reported to reduce the $F / B$ biomass ratio (Bardgett et al., 1999b; Bloem et al., 2004), while organic matter with a high $\mathrm{C} / \mathrm{N}$ ratio stimulates fungal growth and thus increases the $F / B$ ratio (Alexander, 1977; Henriksen and Breland, 1999; Vinten et al., 2002). $\mathrm{pH}$ has been seen to have either a positive or a negative effect on $F / B$ ratio (Bååth and Anderson, 2003; Blagodatskaya and Anderson, 1998).

Higher fungal/bacterial $(F / B)$ biomass ratios are suggested to be indicative for a more sustainable agroecosystem with lower impact on the environment, in which organic matter decomposition and $\mathrm{N}$ mineralisation dominate the provision of plant nutrients for crop growth (Bardgett and McAlister, 1999; Bardgett et al., 1999a; Beare et al., 1992; Yeates et al., 1997). Because of the higher $\mathrm{C} / \mathrm{N}$ ratio of fungi compared to bacteria (10 vs. 4), grazing by fungivores results in a lower $\mathrm{N}$ mineralisation rate than grazing by bacterivores. In addition, fungalfeeding fauna generally have a smaller biomass and lower turnover rates than bacterial-feeding fauna (Didden et al., 1994; Zwart et al., 1994). A fungi-dominated food web may therefore result in a lower $\mathrm{N}$-mineralisation rate. This, however, does not necessarily lead to a lower crop production. The biomass of mycorrhizal fungi probably increases at lower soil nutrient contents (Mäder et al., 2000; Smith and Read, 1997). Their contribution to nutrient uptake may counterbalance the negative effects of a low nutrient availability to the crop and thus reduce nutrient losses to the environment (Jeffries and Barea, 1994; Smith and Read, 1997).

If an increased $F / B$ biomass ratio has a positive effect on crop nutrient uptake efficiency and nutrient retention it is desirable to get a handle on management practices and soil properties that increase this ratio. The aim of this study was, therefore, to find out which management practices and soil characteristics affect the $F / B$ biomass ratio in a Dutch grassland agroecosystem, and whether the $F / B$ ratio can be used as an indicator for a system with low nutrient losses.

We hypothesise an increased fungal biomass and/or $F / B$ ratio: (1) at lower availability of inorganic $\mathrm{N}$; (2) as a consequence of application of manure with higher $\mathrm{C} / \mathrm{N}$ ratio; (3) when farmyard manure is applied superficially compared to slit injection of slurry. We furthermore hypothesise that a higher $F / B$ ratio reduces $\mathrm{N}$ leaching potential. We evaluate factors related to fertiliser regime and management, i.e. plant species composition and organic matter characteristics together with $\mathrm{pH}$ as predictors for the $F / B$ biomass ratio or fungal and bacterial biomass alone.

\section{Materials and methods}

\subsection{Sampling site}

A field trial was done in a pasture of the organic experimental farm "Aver Heino" at Heino in the eastern part of The Netherlands $\left(52^{\circ} 25^{\prime}\right.$ north and $6^{\circ} 15^{\prime}$ east), which was sown with a grass-clover mixture in 1997. After a period of grazing and mowing the field trial was established in 2001. The humid sandy soil was classified as a gleyey sand with a semi-permeable loam horizon at $70-80 \mathrm{~cm}$.

The trial consisted of seven rows, corresponding to three manure treatments: no manure (one row), farm yard manure (three rows) and slurry (three rows). The three rows of farm yard manure and slurry received manure at three different $\mathrm{N}$ application rates: 40, 80 and $120 \mathrm{~kg} \mathrm{Nha}^{-1}$. Each of the seven rows was subdivided into nine subplots which differed in crop: grass (Lolium perenne L.) or grass-clover (Lolium perenne L. and Trifolium repens $\mathrm{L}$.). Dimensions of the subplots were $15 \mathrm{~m} \times 2.7 \mathrm{~m}$, bordered by a $0.3 \mathrm{~m}$ bufferzone. In each row a number of 
Table 1

Treatments of the field trial

\begin{tabular}{|c|c|c|c|c|c|c|}
\hline Crop & Treatment & $n$ & Manure type and application & $\begin{array}{l}\mathrm{N} \text { total } \\
\left(\mathrm{kg} \mathrm{ha}^{-1} \mathrm{y}^{-1}\right)\end{array}$ & $\begin{array}{l}\mathrm{P}_{2} \mathrm{O}_{5} \text { total } \\
\left(\mathrm{kg} \mathrm{ha}^{-1} \mathrm{y}^{-1}\right)\end{array}$ & $\begin{array}{l}\mathrm{K}_{2} \mathrm{O} \text { total } \\
\left(\mathrm{kg} \mathrm{ha}^{-1} \mathrm{y}^{-1}\right)\end{array}$ \\
\hline \multirow[t]{7}{*}{ Grass-clover } & No manure & 4 & No & 0 & 107 & 372 \\
\hline & FYM 40 & 4 & Farm yard manure, superficial & 40 & 107 & 372 \\
\hline & FYM 80 & 4 & Farm yard manure, superficial & 80 & 107 & 372 \\
\hline & FYM 120 & 4 & Farm yard manure, superficial & 120 & 107 & 372 \\
\hline & Slurry 40 & 4 & Slurry, injection & 40 & 107 & 372 \\
\hline & Slurry 80 & 4 & Slurry, injection & 80 & 107 & 372 \\
\hline & Slurry 120 & 4 & Slurry, injection & 120 & 107 & 372 \\
\hline \multirow[t]{4}{*}{ Grass } & No manure & 4 & No & 0 & 122 & 487 \\
\hline & Slurry 40 & 2 & Slurry, injection & 40 & 122 & 487 \\
\hline & Slurry 80 & 2 & Slurry, injection & 80 & 122 & 487 \\
\hline & Slurry 120 & 2 & Slurry, injection & 120 & 122 & 487 \\
\hline
\end{tabular}

subplots was sampled. For a detailed overview of treatments see Table 1. Growth of white clover in grass plots was inhibited by the herbicide Starane.

The $\mathrm{C} / \mathrm{N}$ ratio of the farm yard manure was 12.3 and of the slurry 6.8. All plots received potassium and phosphorus additionally at a rate of $107 \mathrm{kgP}_{2} \mathrm{O}_{5}$ ha $^{-1}$ and $372 \mathrm{~kg} \mathrm{~K}_{2} \mathrm{O} \mathrm{ha}^{-1}$ for grass-clover and $122 \mathrm{~kg} \mathrm{P}_{2} \mathrm{O}_{5} \mathrm{ha}^{-1}$ and $487 \mathrm{~kg} \mathrm{~K}_{2} \mathrm{O} \mathrm{ha}^{-1}$ for grass. Farm yard manure was applied superficially while slurry was applied through slit injection. Both were applied in spring.

\subsection{Soil and crop characteristics}

Soil samples were collected in October 2003, three growing seasons after establishment of the trial. For each plot a bulk sample of 30 cores $(0-10 \mathrm{~cm}$ depth, $3.5 \mathrm{~cm}$ diam.) was collected, sieved ( $5 \mathrm{~mm}$ mesh size), homogenised and stored at field moisture content overnight at $4{ }^{\circ} \mathrm{C}$ before analysis (Bloem et al., 2006). An additional sample was taken for the determination of bulk density (Elliott et al., 1999).

Soil dry matter content was determined after ovendrying of approximately $30 \mathrm{~g}$ of the bulk sample (in duplicate) at $105^{\circ} \mathrm{C}$. Prior to further analysis bulk samples were oven-dried at $40^{\circ} \mathrm{C}$. Organic matter content was determined by loss-on-ignition (Ball, 1964) and $\mathrm{pH}$ of the samples was measured in $1 \mathrm{M} \mathrm{KCl}(\mathrm{pH}-\mathrm{KCl})$. Total soil $\mathrm{N}$ was determined by digestion with $\mathrm{H}_{2} \mathrm{SO}_{4}$, salicylic acid, $\mathrm{H}_{2} \mathrm{O}_{2}$ and selenium as described by Novozamsky et al. (1984) and measured by Segmented Flow Analysis (Skalar, Breda). $\mathrm{C} / \mathrm{N}$ ratio of the soil was calculated from total $\mathrm{N}$ and organic matter percentage, assuming $58 \%$ of organic matter to be C.

Water-extractable phosphorus (Pw) (Sissingh, 1971) and ammonium lactate-acetic acid-extractable $\mathrm{P}(\mathrm{P}-\mathrm{Al})$ were determined (Schouwenburg and Walinga, 1967). Extracts were analysed by spectrophotometry.

Potassium content $(\mathrm{K}-\mathrm{HCl})$ was analysed by shaking approximately $10 \mathrm{~g}$ of soil with $100 \mathrm{ml}$ of extraction solution $(0.2 \mathrm{M} \mathrm{HCl}$ and $0.4 \mathrm{M}$ oxalic acid). The suspension was shaken for $1 \mathrm{~h}$, filtered and measured by Eppendorf Elex 6361 Flame-AES.

The field trial was mown in five cuts: $5 / 13,6 / 26,8 / 2,8 / 28$ and $10 / 9 / 2003$. Herbage was analysed for N, P, and K contents as described by Novozamsky et al. (1983) and measured by Segmented Flow Analysis. For every plot total production and clover production were calculated in tons dry matter per hectare.

\subsection{Fungal and bacterial biomass}

Two hundred g soil was pre-incubated at $50 \%$ WHC (water holding capacity) at $12{ }^{\circ} \mathrm{C}$ for four weeks to stabilise soil conditions and to avoid effects of temperature and moisture fluctuations in the field (Bloem et al., 2006). For each sample, $20 \mathrm{~g}$ of soil and $190 \mathrm{ml}$ of demineralised water were homogenised in a blender (Waring, New Hartford, Conn.) for $1 \mathrm{~min}$ at maximum speed $\left(20,000 \mathrm{rev} \mathrm{min}^{-1}\right)$. A $9 \mathrm{ml}$ sample was fixed by adding $1 \mathrm{ml}$ of $37 \%$ formaldehyde. The soil suspension was resuspended and after $2 \mathrm{~min}$ of settling $10 \mu \mathrm{l}$ of the soil suspension was evenly smeared in a circle of $12 \mathrm{~mm}$ diameter on a printed glass slide (Cel-line Associates Inc., Vineland, NJ, USA). The water-repellent coating keeps the suspension in defined area of $113 \mathrm{~mm}^{2}$. The hole was precleaned with $70 \%$ ethanol and washing-up liquid (Dreft). Slides with soil suspension were then air-dried (Bloem and Vos, 2004).

Slides for counting of fungi were stained for $1 \mathrm{~h}$ with differential fluorescent stain (DFS) solution. The stain solution consisted of $3.5 \mathrm{gl}^{-1}$ europium chelate (Kodak cat no. 1305515, Eastman Fine Chemicals, Rochester NY, USA) and $50 \mathrm{mg}^{-1}$ fluorescent brightener, C40H42N120O10S2 Na2 (FW 960.9, Fluostain I, cat no. F0386, Sigma Chemical Co., St. Louis MD, USA) in 50\% ethanol, filtered through a $0.2 \mu \mathrm{m}$ pore-size membrane. Europium chelate stains DNA and RNA red, FB stains cellulose and polysaccharide (cell walls) blue. After staining the slides were rinsed three times in a bath of $50 \%$ ethanol. After air-drying a coverslip was mounted with immersion oil. 
Fungi were counted under an epifluorescence microscope at $400 \times$ magnification. Blue hyphae were assumed to be inactive or dead, red hyphae were assumed active. Unstained (melanin-forming) hyphae were also counted. Hyphal lengths are estimated by counting the number of intersections of hyphae with the lines of a counting grid. Hyphal length $\left(\mu \mathrm{mrid}^{-1}\right.$ ) was calculated as $H=I \pi A / 2 L$, where $I=$ number of intersections per grid, $A=$ grid area, $L=$ total length of lines in the counting grid. The total length of fungal hyphae $F\left(\mathrm{~m} \mathrm{~g}^{-1}\right.$ soil) was calculated as $F=H \times 10^{-6}(A / B)(1 / S)$, where $H=$ hyphal length, $A=$ area of the slide covered by sample, $B=$ area of the grid and $S=$ amount of soil on the filter. Biovolumes can be calculated from length $L$ and width $W$ using the equation $V=(\pi / 4) W^{2}(L-W / 3)$. Fungal biomass was calculated assuming a mean hyphal diameter (width) of $2.5 \mu \mathrm{m}$ and a specific carbon content of $1.3 \times 10^{-13}{\mathrm{~g} \mathrm{C} \mu \mathrm{m}^{-3}}^{-}$(Bakken and Olsen, 1983; Veen and Paul, 1979).

Slides for counting of bacteria were stained for $30 \mathrm{~min}$ with the fluorescent protein dye 5-(4,6-dichlorotriazin-2-yl) aminofluorescein (DTAF). This solution consisted of $2 \mathrm{mg}$ DTAF dissolved in $10 \mathrm{ml}$ buffer solution $(0.05 \mathrm{M}$ $\mathrm{Na}_{2} \mathrm{HPO}_{4}\left(7.8 \mathrm{gl}^{-1}\right)$ and $0.85 \% \mathrm{NaCl}\left(8.5 \mathrm{gl}^{-1}\right)$, adjusted to $\mathrm{pH} 9$ ), filtered through a $0.2 \mu \mathrm{m}$ pore-size membrane. After staining the slides were rinsed three times with buffer. After air-drying a coverslip was mounted with immersion oil (Bloem and Vos, 2004). On the stained slides, bacterial numbers and cell volumes were measured automatically with a confocal laser-scanning microscope (Leica TCS SP2) combined with image analysis software (Leica Qwin pro) as described by Bloem et al. (1995). Bacterial biomass (C) was estimated from the biovolume using a specific carbon

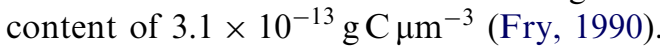

Note that the specific carbon content used for bacteria is 2.4 times higher than that used for fungi. This means that our fungal to bacterial biomass ratios based on carbon are 2.4 times lower than ratios based on biovolume (Velvis, 1997).

\subsection{Bacterial activity}

Bacterial growth rate was determined as the incorporation of $\left[{ }^{3} \mathrm{H}\right]$ thymidine and $\left[{ }^{14} \mathrm{C}\right]$ leucine into bacterial DNA and proteins (Bloem and Bolhuis, 2006; Michel and Bloem, 1993). [Methyl- ${ }^{3} \mathrm{H}$ ] Thymidine $\left(925 \mathrm{GBq} \mathrm{mmol}^{-1}\right)$ and L[U- $\left.{ }^{14} \mathrm{C}\right]$ leucine $\left(11.5 \mathrm{GBq} \mathrm{mmol}^{-1}\right)$ were purchased from Amersham Ltd., Amersham, UK. Per sample (tube) we used $1.5 \mu 1{ }^{14} \mathrm{C}$ leucine, $2.0 \mu 1{ }^{3} \mathrm{H}$ thymidine and $16.5 \mu 1$ unlabelled thymidine $\left(2.35 \mathrm{mg}^{-1}\right)$. This corresponds with $2 \mu \mathrm{M}$ and $2.78 \mathrm{kBq}{ }^{14} \mathrm{C}$ leucine and $2 \mu \mathrm{M}$ and $74 \mathrm{kBq}{ }^{3} \mathrm{H}$ thymidine per tube. Twenty g soil and $95 \mathrm{ml}$ Prescott and James's mineral salt solution (P\&J medium, Prescott and James (1955)) were shaken by hand in a bottle for $30 \mathrm{~s}$. Hundred $\mu 1$ of soil suspension was added to $20 \mu 1$ labelled thymidine and leucine in a $13 \mathrm{ml}$ polypropylene centrifuge tube with screw cap. After $1 \mathrm{~h}$ incubation the incorporation was stopped by adding $5 \mathrm{ml}$ of $0.3 \mathrm{~N} \mathrm{NaOH}, 25 \mathrm{mM}$ EDTA and $0.1 \%$ SDS. Blanks were prepared by adding the extraction mixture immediately after the start of the incubation. Macromolecules (DNA and proteins) were extracted at $30^{\circ} \mathrm{C}$ for $18-20 \mathrm{~h}$ (overnight). The suspension was mixed and centrifuged for $40 \mathrm{~min}$ at $5000 \times g$

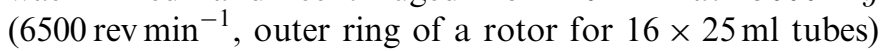
at $25^{\circ} \mathrm{C}$ in an MSE high speed 18 centrifuge. The supernatant was aspired in a $13 \mathrm{ml}$ tube and cooled on ice. After $5 \mathrm{~min}, 1.3 \mathrm{ml}$ ice-cold $1 \mathrm{~N} \mathrm{HCl}$ and $1.3 \mathrm{ml}$ ice-cold $29 \%$ TCA $(\mathrm{w} / \mathrm{v})$ were added. The suspension was cooled further for at least $15 \mathrm{~min}$. The precipitated macromolecules (DNA and proteins) were collected on a $0.2 \mu \mathrm{m}$ pore size cellulose nitrate filter (BA 83, Schleicher \& Schuell). The filters were washed three times with $5 \mathrm{ml}$ ice-cold $5 \%$ TCA. The filters were transferred to glass scintillation vials and $1 \mathrm{ml} 0.1 \mathrm{~N}$ $\mathrm{NaOH}$ and $1 \mathrm{ml}$ ethylacetate were added to dissolve macromolecules and filters. Fifteen ml Ready Safe scintillation cocktail (Beckman Instruments, Fullerton, CA, USA) was added and radioactivity was counted in an LKB Wallac 1215 liquid scintillation counter (LKB Instruments, Turku, Finland). Blanks were substracted and the counted dpm were multiplied by 0.0028378 to calculate pmol thymidine incorporated per gram soil per hour, and by 0.07587 to calculate pmol leucine incorporated per gram soil per hour.

\section{5. $N$ leaching}

Two ceramic cup samplers were placed in each field plot at a depth of $30 \mathrm{~cm}$ below the soil surface. A weather station was situated on the farm and meteorological data were obtained daily from the KNMI (Royal Dutch Meteorological Institute) website. The cups were sampled after $50 \mathrm{~mm}$ of precipitation during January and February 2004. Pore water samples were analysed for $\mathrm{NO}_{3}^{-}$and $\mathrm{NH}_{4}^{+}$ using Segmented Flow Analysis (Houba et al., 2000).

$\mathrm{N}$ leaching was calculated by multiplying the average concentration of two sampling dates with the precipitation surplus in the period in between (De Vos and Assink, 2004; Smit et al., 2004).

\subsection{Partial $N$ balance}

A partial $\mathrm{N}$ balance (IN-OUT) was calculated for each plot. Inputs of the budget were: fertiliser, $\mathrm{N}_{2}$ fixation and atmospheric deposition. Biological $\mathrm{N}_{2}$ fixation by Rhizobium in symbiosis with white clover was estimated using the formula given by Carlsson and Huss-Danell (2003). Atmospheric deposition was assumed to be $50 \mathrm{~kg} \mathrm{ha}^{-1}$ for the eastern part of The Netherlands (Aarts et al., 2000). Output of the budget was crop yield. Unknown items were leaching and gaseous losses.

\subsection{Statistical analysis}

Statistical analysis was carried out using the statistical package SPSS (SPSS Inc., Chicago, IL). $F / B$ ratio was transformed using the arcsine square root to meet the 
requirements of normality and homogeneity of variances. Stepwise forward multiple linear regression analysis was used to elucidate relationships of soil characteristics and management with microbial biomass and activity.

Treatment effects on microbial parameters were analysed by a two-way ANOVA, because the layout of the trial did not permit the comparison of the seven manure treatments. The factors were manure type (no manure, farmyard manure and slurry) and $\mathrm{N}$ application rate $(0,40,80$ and $120 \mathrm{~kg} \mathrm{Nha}^{-1}$ ). This was done for grass-clover and grass separately because degrees of freedom were insufficient for a three-way ANOVA with crop, manure type and $\mathrm{N}$ application rate. These analyses were followed by Tukey's test to detect differences between treatments. Differences between grass-clover and grass, and between the control and slurry for grass, were analysed using T-tests.

\section{Results}

\subsection{Soil and crop characteristics}

$\mathrm{pH}$ values in the trial ranged from 4.4 to 4.8 , being significantly lower in grass-clover treatments than in grass (Table 2). In grass-clover $\mathrm{pH}$ increased with increasing $\mathrm{N}$ application rate and this tendency could also be seen in grass. Plots receiving farm yard manure had a higher $\mathrm{pH}$ than no manure in grass-clover; slurry had a higher $\mathrm{pH}$ than no manure in grass.

In grass the soil $\mathrm{C} / \mathrm{N}$ ratio was higher in the plots with no manure than in the slurry treatments (Table 2). Though not significantly different, organic matter content was higher in grass-clover than in grass, and tended to increase with the application rate of $(\mathrm{N})$ fertilisation. Although soil $\mathrm{C} / \mathrm{N}$ ratios did not differ significantly between grass-clover and grass, $\mathrm{N}$ content in the removed crop (aboveground) did. Total production and $\mathrm{N}$ yield were higher in grass-clover than in grass, but showed no relation with $\mathrm{N}$ application rate and fertiliser type.

Soil potassium contents in the trial ranged from 71 to $270 \mathrm{mg} \mathrm{K}_{2} \mathrm{O} 100 \mathrm{~g}^{-1}$ and were classified as "sufficient" to "very high" according to Dutch standards (Evers et al., 2000). In grass-clover the potassium content was significantly affected by manure type and $\mathrm{N}$ application level. Slurry had lower potassium content than no manure and farm yard manure treatments. $\mathrm{N}$ application level did not have a consistent effect.

The average values of $\mathrm{Pw}$ and $\mathrm{P}-\mathrm{Al}$ for all fields were, respectively, $19 \pm 5$ and $43 \pm 8 \mathrm{mg} \mathrm{P}_{2} \mathrm{O}_{5} 100 \mathrm{~g}^{-1}$, which are classified as "sufficient". Total soil $\mathrm{N}$ was $2.3 \pm 0.3 \mathrm{mg} \mathrm{kg}^{-1}$. Bulk density was higher in the no manure treatments than in the other treatments and ranged from 1.40 to $1.58 \mathrm{~g} \mathrm{~cm}^{-3}$. Dry matter percentage of the entire field was $85 \pm 2$.

\subsection{Microbial biomass and activity}

On average, fungal biomass constituted $25 \pm 7 \%$ of the total microbial biomass in the field trial and ranged from 19.2 to $46.0 \mu \mathrm{g} \mathrm{Cg}^{-1}$. Bacterial biomass was $81.0 \pm$ $16.1 \mu \mathrm{g} \mathrm{Cg}^{-1}$ for the entire field and thymidine and leucine incorporation averaged, respectively, $14.4 \pm 4.9$ and $277.6 \pm 55.9 \mathrm{pmol} \mathrm{g}^{-1} \mathrm{~h}^{-1}$ for all treatments together. The $F / B$ biomass ratio varied between 0.25 and 0.46 .

Fungal and bacterial biomass, bacterial activity and the $F / B$ ratio were significantly affected by management and soil properties.

Table 2

Soil characteristics and yield data

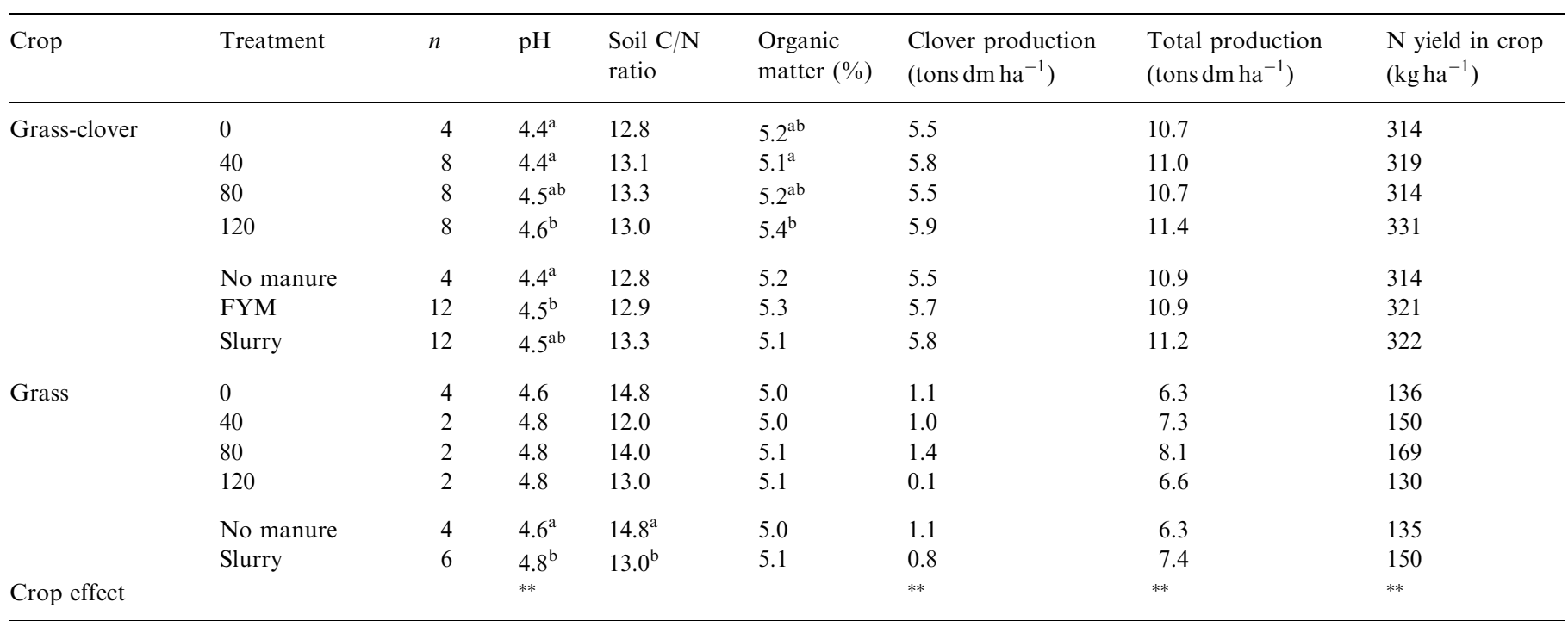

Values denoted with the same letter are not significantly different (Tukey's post hoc test, $P<0.05$ or T-test, $P<0.05$ ). Comparisons were made for $\mathrm{N}$ application rates and manure types separately. Asterisks in the crop effect row indicate significant differences (T-test, ${ }^{*} P<0.05$, $\left.{ }^{* *} P<0.01\right)$ between grassclover and grass. 


\subsubsection{Management effects}

3.2.1.1. Crop. The differences between grass and grassclover treatments were large and highly significant. Fungal biomass in grass treatments was almost two-fold higher than in grass-clover treatments $(38.6 \pm 9.8$ vs. $25.2 \pm 7.2 \mu \mathrm{g} \mathrm{Cg}^{-1}$, T-test, $P<0.001$ ) (Fig. 1). Also bacterial biomass, which was $94.4 \pm 14.2 \mu \mathrm{g} \mathrm{Cg}^{-1}$ in grass and $79.1 \pm 14.2 \mu \mathrm{g} \mathrm{Cg}^{-1}$ in grass-clover, and total microbial

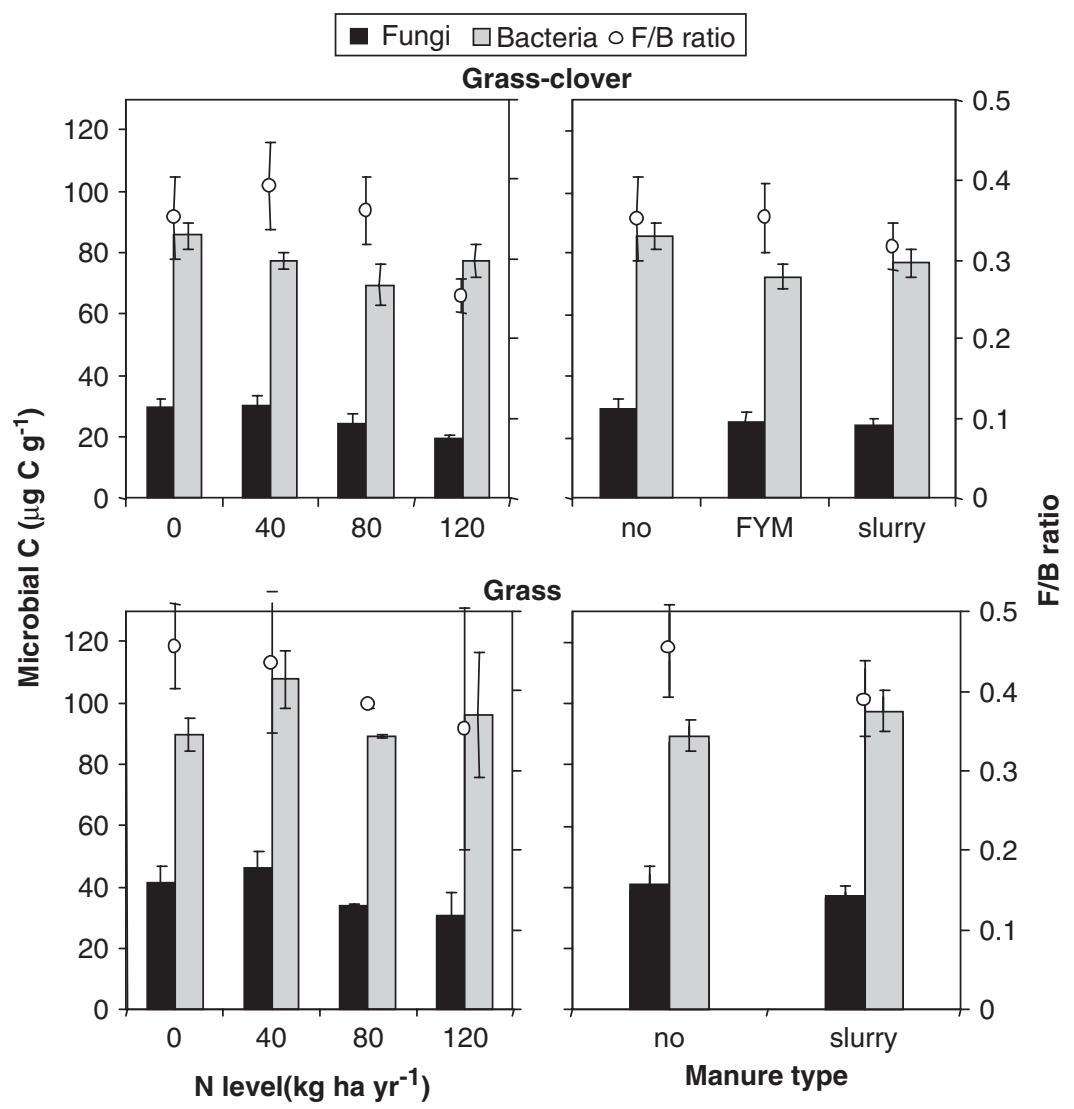

Fig. 1. Fungal and bacterial biomass and $F / B$ ratio for nitrogen level and manure type (No $=$ no manure, FYM $=$ farm yard manure) in grass-clover (top) and grass (bottom). Mean values $\pm \mathrm{SE}$ are shown.

Table 3

Thymidine and leucine incorporation for crop, $\mathrm{N}$ application rate and manure type

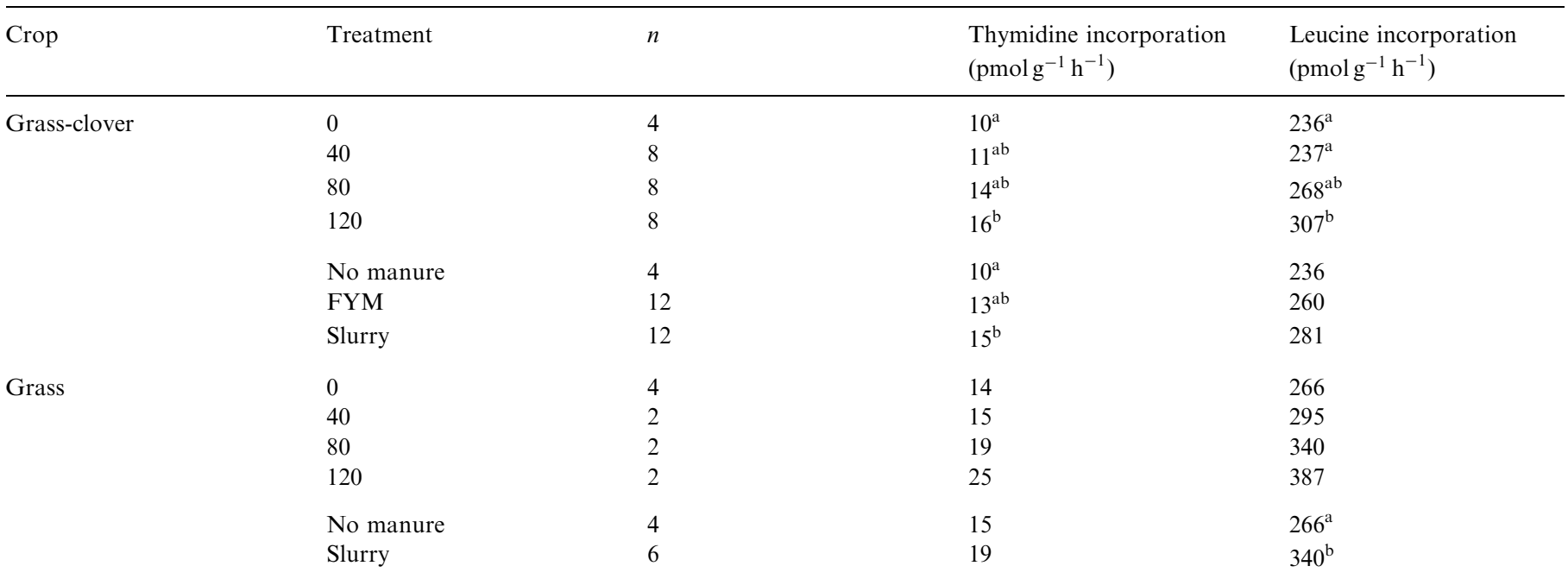

Values denoted with the same letter are not significantly different (Tukey's post hoc test, $P<0.05$ or T-test, $P<0.05$ ). Comparisons were made for $\mathrm{N}$ application rates and manure types separately. 
biomass were significantly higher in grass (T-test, $P=$ 0.007 and $P<0.001$, respectively). This could also been seen for the $F / B$ biomass ratio, which was 0.34 overall for grass-clover and 0.42 for grass (T-test, $P=0.022$ ).

Regression of the $F / B$ ratio with clover production resulted in a weak but significant negative relationship $\left(R^{2}=0.12, P=0.035\right)$.

3.2.1.2. $N$ application rate. Increasing $\mathrm{N}$ application rates reduced the total amount of fungi in the grass-clover treatments (ANOVA, $P=0.014 ;$ Fig. 1). The 0 and $40 \mathrm{~kg} \mathrm{Nha}^{-1}$ treatments had a significantly higher amount of fungi than the $120 \mathrm{~kg} \mathrm{Nha}^{-1}$ treatment. In the grass treatments this trend could also be seen but was not statistically significant (Fig. 1). The amount of active fungi followed the same trend (data not shown), but without significant differences. No significant effect of $\mathrm{N}$ application rate was found on bacterial biomass. For grass-clover thymidine and leucine incorporation were highest in the $120 \mathrm{~kg} \mathrm{Nha}^{-1}$ treatment (ANOVA, $P=0.027$ and $P=$ 0.007 respectively, Table 3 ). $\mathrm{N}$ application rate had a significant negative main effect on the $F / B$ biomass ratio $(P=0.034)$.

3.2.1.3. Manure type. There was no effect of manure type on fungal and bacterial biomass (Fig. 1). For grass-clover an interaction-effect was seen of $\mathrm{N}$ application rate and manure type on fungal biomass and $F / B$ ratio $(P=0.025)$.

\subsubsection{Relations with soil characteristics}

3.2.2.1. $p H$. The $F / B$ biomass ratio decreased with increasing $\mathrm{pH}$ for grass-clover and grass separately (Fig. 2). Thymidine and leucine incorporation both had a significant positive relationship with $\mathrm{pH}$. When these regressions were separated for grass-clover and grass significant relationships were found for thymidine incorporation $\left(R^{2}=0.42, P<0.001\right.$ and $\left.R^{2}=0.60, P=0.008\right)$ as well as for leucine incorporation $\left(R^{2}=0.47, P<0.001\right.$ and $R^{2}=0.74, P=0.001$, Fig. 2).

3.2.2.2. Organic matter quality and quantity. No significant relationship with microbial biomass or $F / B$ ratio was found for $\mathrm{C} / \mathrm{N}$ ratio and organic matter percentage. Neither thymidine nor leucine incorporation and $\mathrm{CO}_{2}$ evolution showed any relationship with organic matter characteristics.

\section{3. $N$ leaching}

The $\mathrm{N}$ leaching in grass-clover treatments was significantly higher than in grass (T-test, $P<0.001$, Fig. 3). Multiple regression analysis with management and soil characteristics $(\mathrm{N}$ application rate, manure type, clover production, $\mathrm{C} / \mathrm{N}$ ratio, $\mathrm{pH}$, organic matter percentage, fungal and bacterial biomass) pointed out that $\mathrm{pH}$ and $\mathrm{N}$ application rate determined leaching $\left(R^{2}=0.53, P<0.001\right)$. Leaching increased with higher $\mathrm{N}$ application rates and
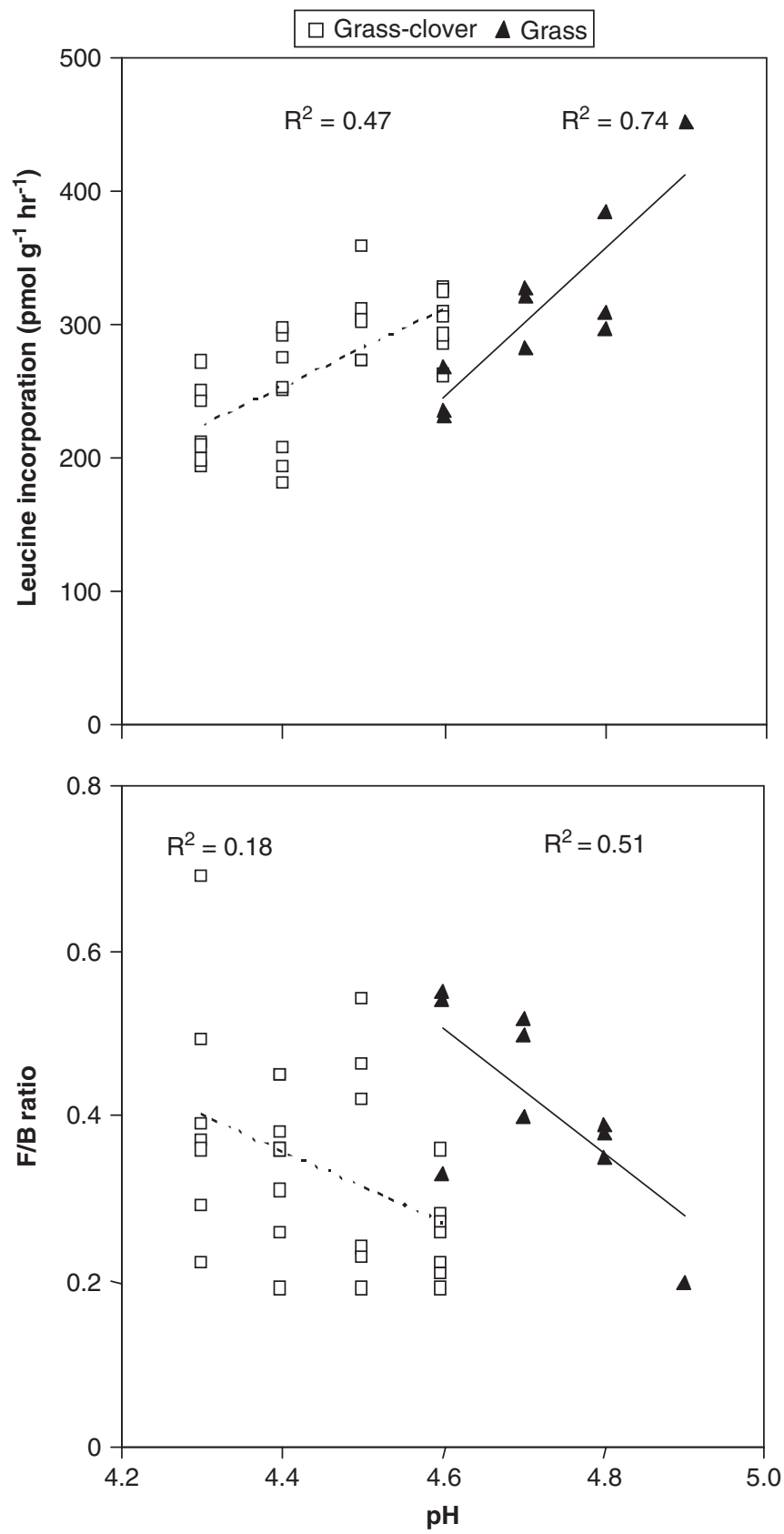

Fig. 2. Relationship between leucine incorporation, $F / B$ ratio and $\mathrm{pH}$ for grass-clover and grass. Markers represent observations, lines represent regressions, for grass-clover (dashed, $P=0.025$ ) and for grass (solid, $P=0.021)$.

decreasing $\mathrm{pH}$-values. No correlation with fungal biomass or $F / B$ ratio was found when all single observations were used separately. This was caused by the large variation of the fungal biomass. However, when regression was performed with the means of treatments a negative relationship with fungal biomass was revealed (Fig. 4).

\subsection{Partial $N$ balance}

$\mathrm{N}$ application rate had a significant main effect on the partial $\mathrm{N}$ balance (ANOVA, $P<0.001$ ). The partial $\mathrm{N}$ 


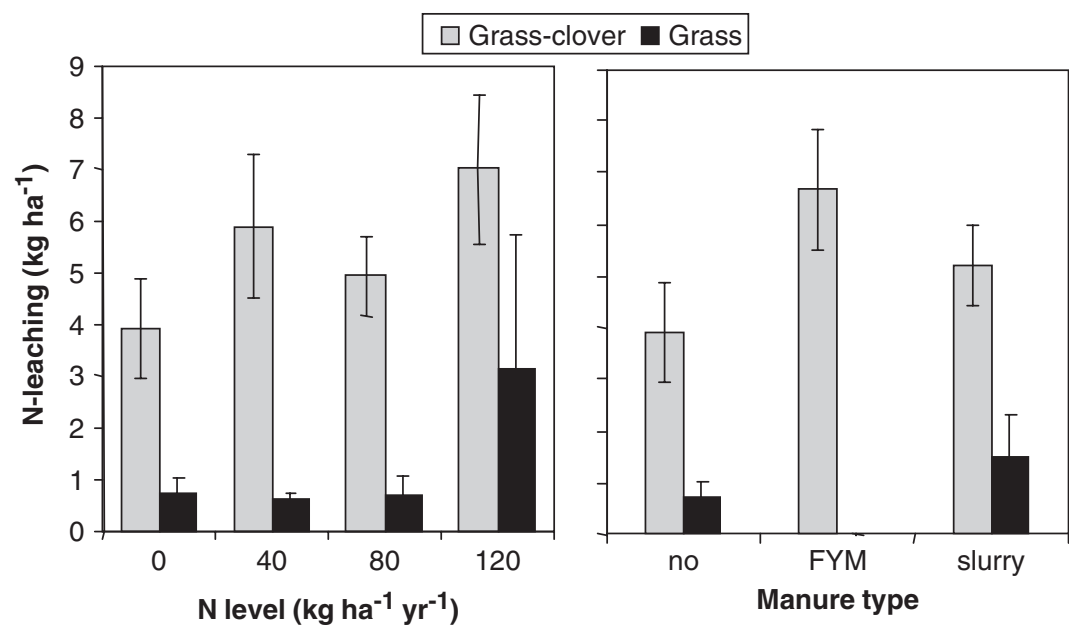

Fig. 3. Nitrogen leaching between January 16 and February 17 at a depth of $30 \mathrm{~cm}$ in grass-clover and grass, for manure type (No $=$ no manure, FYM $=$ farm yard manure) and nitrogen level. Mean values \pm SE are shown.

balance was negative at the lowest $\mathrm{N}$ application rates $\left(0\right.$ and $\left.40 \mathrm{~kg} \mathrm{ha}^{-1}\right)$, and positive at high $\mathrm{N}$ application rates $\left(80\right.$ and $\left.120 \mathrm{~kg} \mathrm{ha}^{-1}\right)$. Stepwise multiple regression analysis included $\mathrm{N}$ application rate and $\mathrm{pH}\left(R^{2}=0.82, P<0.001\right)$, in which the partial $\mathrm{N}$ balance was higher with increasing $\mathrm{N}$ application rate and $\mathrm{pH}$. No correlation was found for partial $\mathrm{N}$ balance with $\mathrm{N}$ leaching. Regressions with fungal biomass and $F / B$ ratio both resulted in a weak, significant negative relationship $\left(R^{2}=0.12, P=0.034\right.$ and $R^{2}=0.11, P=0.040$, respectively). When regression was done with means for treatments of the partial $\mathrm{N}$ balance with fungal biomass a significant negative relationship with a higher correlation coefficient was the result (Fig. 4). Here, treatments were not split up for grass-clover and grass as no crop effect was present on the $\mathrm{N}$ balance.

\section{Discussion}

The bacterial biomasses we found were somewhat lower than Bloem and Breure (2003) found in grasslands, but twice as high as the biomasses Van der Wal et al. (2006) found in agricultural sites, ex-arable fields and heathlands. The fungal biomasses we found were comparable with biomasses found by Van der Wal et al., which, in combination with our higher bacterial biomasses, resulted in lower $F / B$ biomass ratios in our fields. Bittman et al. (2005) found higher $F / B$ ratios in grass swards, which was mainly caused by higher fungal biomass. It should be noted that factors used for converting bacterial numbers and hyphal lengths into biomass-values differed from ours. Often measures of fungal and bacterial biomass are made using phospholipid fatty acid analysis (Bardgett et al., 1996; Frostegard and Bååth, 1996). $F / B$ ratios are then expressed as fungal PLFA/bacterial PLFA. Because of all the different methods and conversion factors for calculating $F / B$ ratios, it is questionable to compare different studies.
In this study, fungal and bacterial biomass and the $F / B$ ratio showed remarkably quick responses to changes in management and fertiliser regime. Already within three growing seasons after the start of the experiment fungi responded to crop and to $\mathrm{N}$ application rates.

In line with our first hypothesis, the $F / B$ ratio decreased with increasing $\mathrm{N}$ application rate. This was mainly caused by a decrease of fungal biomass, while bacterial biomass remained approximately constant with increasing $\mathrm{N}$ application rate (Fig. 1). Both fungal and bacterial biomasses were lower under grass-clover than under grass.

In contrast to our hypothesis, manure type did not seem to be of much importance for determining $F / B$ ratio and microbial biomass. Probably, the $\mathrm{C} / \mathrm{N}$ ratios of the two manure types, 6.8 for slurry vs. 12.3 for farmyard manure, were not high enough to enhance fungi. Organic matter that has been reported to stimulate fungal growth had C/N ratios of 20 or higher (Vinten et al., 2002). Moreover, it often takes much longer than two years (decades) before changes in manure type have clear effects on soil organic matter quality and soil organisms (Bloem et al., 1997; Mäder et al., 2000; Bloem et al., 2004). Furthermore, the knives of the slit-injector may have been to far apart $(20 \mathrm{~cm})$ to have a detrimental effect on mycelial networks.

The presence of white clover had a negative effect on fungal biomass and $F / B$ ratio. This result seems to be in contrast with reports on a higher arbuscular mycorrhizal colonisation in clover than in grass (Ryan and Ash, 1999; Zhu et al., 2000). This was attributed to the finer branched root system and root hairs of grass, which makes it less dependent on mycorrhizal fungi. Gamper et al. (2004), however, found higher levels of colonisation in ryegrass compared to white clover. It should be recognised that a higher level of colonisation (expressed as percentage of root length infected) does not necessarily mean also a higher biomass of mycorrhizal hyphae per gram of soil. Moreover, we do not know which fraction of the total fungal biomass consists of mycorrhizas and which fraction 

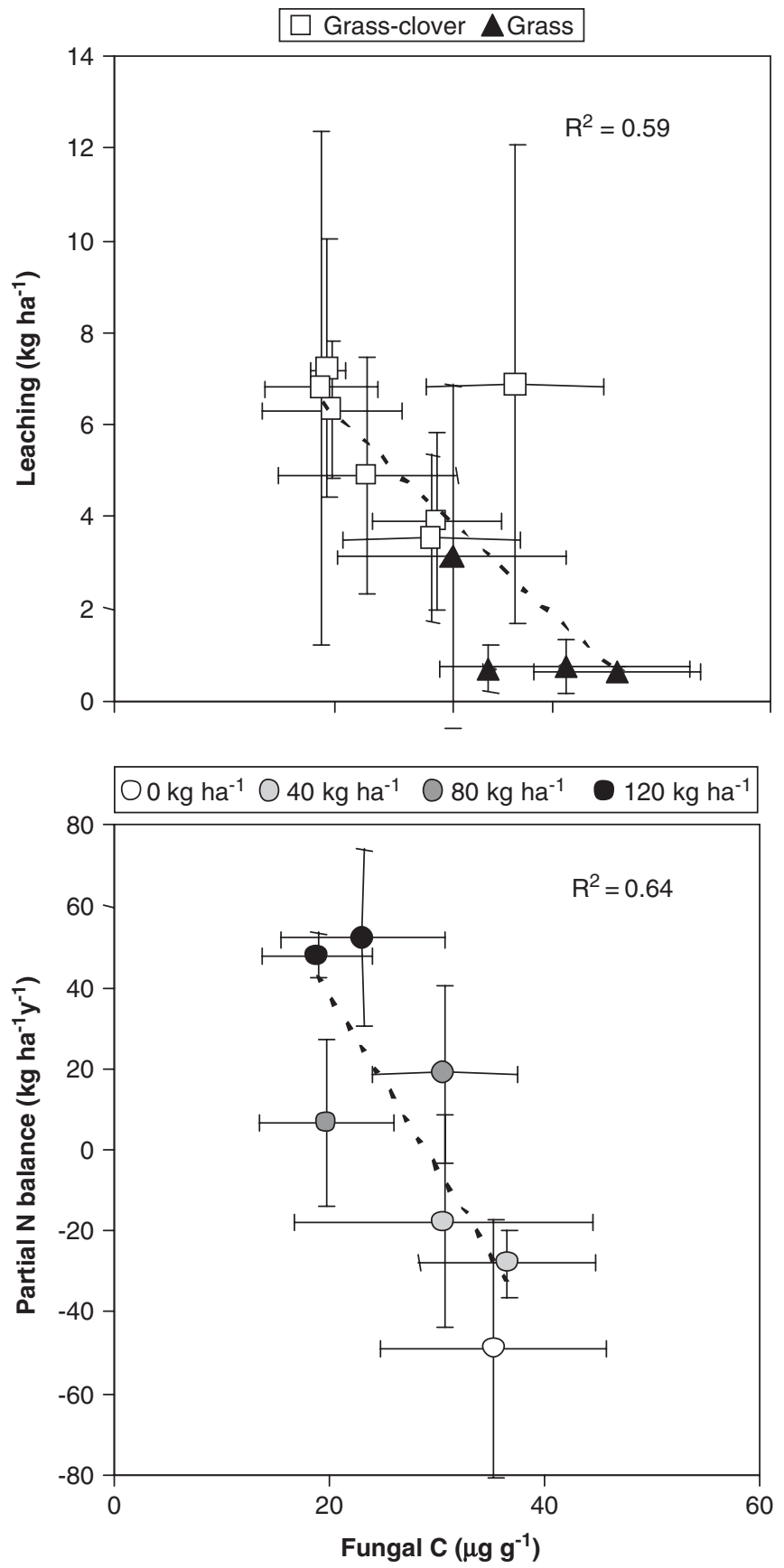

Fig. 4. Relationship between means of leaching and partial $\mathrm{N}$ balance and fungal biomass. Markers indicate means per treatment (see Table 1). Bars represent standard deviations, dashed lines represent regression with means (upper graph $P=0.006$, lower graph $P=0.03$ ).

consists of saprophytic fungi. Not only fungal biomass but also bacterial biomass and activity were greater under grass than under grass-clover (Fig. 1, Table 3). This might be a consequence simply of the denser root system, and thus higher rhizosphere/bulk soil ratio, of perennial ryegrass compared to white clover (Schortemeyer et al., 1997). However, white clover has a much higher ammonium exudation than perennial ryegrass (Paynel and Cliquet, 2003) which theoretically might affect fungal abundance negatively and bacterial biomass positively. However, Breland and Bakken (1991) did not find any profound effect of plant species on microbial immobilisation of carbon and nitrate in the rhizosphere.

Although grass-clover mixtures have been reported to have a higher aboveground production (Elgersma and Hassink, 1997), as could also be seen in this study, this did not increase the amount of soil organic matter in the two years the experiment had lasted. Clover can change the $\mathrm{C} / \mathrm{N}$ ratio of the soil organic matter because the litter has a lower $\mathrm{C} / \mathrm{N}$ ratio compared to grass (Neergaard et al., 2002). We did not find a lower $\mathrm{C} / \mathrm{N}$ ratio of the soil organic matter in grass-clover treatments compared to grass treatments, but the $\mathrm{N}$ content of the removed crop was higher in grass-clover than in grass. This implies that the difference in fungal biomass between grass and grass-clover might be attributed to the difference in litter quality.

If more nitrogen in root exudates or litter from white clover suppresses the amount of fungi, this does not explain why bacteria were less abundant in grass-clover than in grass. Some unknown effects of exudates of grass or clover might be involved.

Despite the narrow $\mathrm{pH}$ range in our experiment, we found that the $F / B$ biomass ratio decreased with increasing pH (Fig. 2). This was caused by an increasing bacterial biomass rather than a decreasing fungal biomass. These results were consistent with other reports. Fungi can stand low pH better than bacteria (Swift et al., 1979). Bardgett et al. (1993) reported an increase in the amount of total mycelium with increasing acidity. Also, effects of $\mathrm{pH}$ on the fungal-to-bacterial substrate induced respiration were reported: the respiratory activity of fungi increased with acidification, while that of bacteria decreased (Blagodatskaya and Anderson, 1998). Bååth and Anderson (2003) reported a decreasing $F / B$ respiration ratio with increasing $\mathrm{pH}$, but a slightly increasing $F / B$ biomass ratio (using PLFA technique). Bacterial activity increased with increasing $\mathrm{pH}$, as has been reported several times (Bååth, 1996, 1998; Bååth et al., 1995; Pennanen et al., 1998).

$\mathrm{N}$ leaching was higher in grass-clover than in grass, while fungal biomass was higher in grass. No clear relationship was found for leaching and fungal biomass when single observations were used, but regression analysis with means of treatments resulted in a negative relationship. Also, when analysed in the same way, means of partial $\mathrm{N}$ balance showed a relationship with means of fungal biomass (Fig. 4). A higher fungal biomass thus indicates a system with lower $\mathrm{N}$ fertilisation, which results in a more negative partial $\mathrm{N}$ balance (or smaller $\mathrm{N}$ surplus) and a lower $\mathrm{N}$ leaching potential.

However, a causal relationship cannot be drawn from these results. A field with a higher fungal biomass does not necessarily coincide with a low $\mathrm{N}$ leaching potential. Leaching and the partial $\mathrm{N}$ balance were not correlated indicating that processes unaccounted for, such as volatilisation and denitrification were of differential importance across the treatments. A complete $\mathrm{N}$ balance is needed to 
explain the relationships between fungal biomass, $F / B$ ratio and $\mathrm{N}$ leaching. Our results in general support the suggestion that the $F / B$ ratio is indicative for a sustainable system with lower $\mathrm{N}$ losses, but more observations are needed to confirm the relationship between $F / B$ ratio and sustainability.

\section{Acknowledgements}

We thank An Vos, Meint Veninga and Popko Bolhuis for technical assistance. We thank Thom Kuyper, Ron de Goede, Kor Zwart and Annemieke Smit for support and helpful discussions. Ellen Heeres and the staff of Aver Heino made it possible to use the field trial.

\section{References}

Aarts, H.F.M., Habekotte, B., van Keulen, H., 2000. Nitrogen (N) management in the 'De Marke' dairy farming system. Nutrient Cycling in Agroecosystems 56, 231-240.

Alexander, M., 1977. Introduction to Soil Microbiology. Wiley, New York.

Anderson, J.P.E., Domsch, K.H., 1975. Measurement of bacterial and fungal contributions to respiration of selected agricultural and forest soils. Canadian Journal of Microbiology 21, 314-322.

Bååth, E., 1996. Adaptation of soil bacterial communities to prevailing $\mathrm{pH}$ in different soils. FEMS Microbiology Ecology 19, 227-237.

Bååth, E., 1998. Growth rates of bacterial communities in soils at varying $\mathrm{pH}$ : a comparison of the thymidine and leucine incorporation techniques. Microbial Ecology 36, 316-327.

Bååth, E., Anderson, T.-H., 2003. Comparison of soil fungal/bacterial ratios in a $\mathrm{pH}$ gradient using physiological and PLFA-based techniques. Soil Biology and Biochemistry 35, 955-963.

Bååth, E., Frostegard, A., Pennanen, T., Fritze, H., 1995. Microbial community structure and $\mathrm{pH}$ response in relation to soil organic matter quality in wood-ash fertilized, clear-cut or burned coniferous forest soils. Soil Biology and Biochemistry 27, 229-240.

Bailey, V.L., Smith, J.L., Bolton Jr., H., 2002. Fungal-to-bacterial ratios in soils investigated for enhanced $\mathrm{C}$ sequestration. Soil Biology and Biochemistry 34, 997-1007.

Bakken, L.R., Olsen, R.A., 1983. Buoyant densities and dry-matter contents of microorganisms: conversion of a measured biovolume into biomass Bacteria and fungi from soil. Applied and Environmental Microbiology 45, 1188-1195.

Ball, D.F., 1964. Loss-on-ignition as estimate of organic matter + organic carbon in non-calcareous soils. Journal of Soil Science 15, 84.

Bardgett, R.D., McAlister, E., 1999. The measurement of soil fungal: bacterial biomass ratios as an indicator of ecosystem self-regulation in temperate meadow grasslands. Biology and Fertility of Soils 29, 282-290.

Bardgett, R.D., Frankland, J.C., Whittaker, J.B., 1993. The effects of agricultural management on the soil biota of some upland grasslands. Agriculture Ecosystems and Environment 45, 25-45.

Bardgett, R.D., Hobbs, P.J., Frostegard, A., 1996. Changes in soil fungal: bacterial biomass ratios following reductions in the intensity of management of an upland grassland. Biology and Fertility of Soils 22, 261-264.

Bardgett, R.D., Leemans, D.K., Cook, R., Hobbs, P.J., 1997. Seasonality of the soil biota of grazed and ungrazed hill grasslands. Soil Biology and Biochemistry 29, 1285-1294.

Bardgett, R.D., Lovell, R.D., Hobbs, P.J., Jarvis, S.C., 1999a. Seasonal changes in soil microbial communities along a fertility gradient of temperate grasslands. Soil Biology and Biochemistry 31, 1021-1030.

Bardgett, R.D., Mawdsley, J.L., Edwards, S., Hobbs, P.J., Rodwell, J.S., Davies, W.J., 1999b. Plant species and nitrogen effects on soil biological properties of temperate upland grasslands. Functional Ecology 13, 650-660.

Beare, M.H., Parmelee, R.W., Hendrix, P.F., Cheng, W., 1992. Microbial and faunal interactions and effects on litter nitrogen and decomposition in agroecosystems. Ecological Monographs 62, 569-591.

Beare, M.H., Hus, S., Coleman, D.C., Hendrix, P.F., 1997. Influences of mycelial fungi on soil aggregation and organic matter storage in conventional and no-tillage soils. Applied Soil Ecology 5, 211-219.

Bittman, S., Forge, T.A., Kowalenko, C.G., 2005. Responses of the bacterial and fungal biomass in a grassland soil to multi-year applications of dairy manure slurry and fertilizer. Soil Biology and Biochemistry 37, 613-623.

Blagodatskaya, E.V., Anderson, T.H., 1998. Interactive effects of $\mathrm{pH}$ and substrate quality on the fungal-to-bacterial ratio and $\mathrm{qCO}_{2}$ of microbial communities in forest soils. Soil Biology and Biochemistry 30, 1269-1274.

Bloem, J., Breure, A.M., 2003. Microbial indicators. In: Markert, B.A., et al. (Eds.), Bioindicators/Biomonitors-Principles, Assessment, Concepts. Elsevier, Amsterdam, pp. 259-282.

Bloem, J., Bolhuis, P.R., 2006. Thymidine and leucine incorporation to assess bacterial growth rate. In: Bloem, J., et al. (Eds.), Microbiological Methods for Assessing Soil Quality. CABI, Wallingford, UK.

Bloem, J., Vos, A., 2004. Fluorescent staining of microbes for total direct counts. In: Kowalchuk, G., et al. (Eds.), Molecular Microbial Ecology Manual. Kluwer Academic Publishers, Dordrecht, The Netherlands.

Bloem, J., Lebbink, G., Zwart, K.B., Bouwman, L.A., Burgers, S.L.G.E., De, V.J.A., De, R.P.C., 1994. Dynamics of microorganisms, microbivores and nitrogen mineralisation in winter wheat fields under conventional and integrated management. Agriculture, Ecosystems and Environment 51, 129-143.

Bloem, J., Veninga, M., Shepherd, J., 1995. Fully automatic determination of soil bacterium numbers, cell volumes, and frequencies of dividing cells by confocal laser scanning microscopy and image analysis. Applied and Environmental Microbiology 61, 926-936.

Bloem, J., De Ruiter, P.C., Bouwman, L.A., 1997. Soil food webs and nutrient cycling in agroecosystems. In: van Elsas, J.D., et al. (Eds.), Modern Soil Microbiology. Marcel Dekker, Inc., New York, pp. 245-278.

Bloem, J., Schouten, T., Didden, W., Jagers op Akkerhuis, G., Keidel, H., Rutgers, M., Breure, T., 2004. Measuring soil biodiversity: experiences, impediments and research needs. In: Francaviglia, R. (Ed.), OECD Expert Meeting on Soil Erosion and Soil Biodiversity Indicators, Rome, Italy.

Bloem, J., Schouten, A.J., Sorensen, S.J., Rutgers, M., Van der Werf, A., Breure, A.M., 2006. Monitoring and evaluating soil quality. In: Bloem, J., et al. (Eds.), Microbiological Methods for Assessing Soil Quality. CABI, Wallingford, UK.

Breland, T.A., Bakken, L.R., 1991. Microbial-growth and nitrogen immobilization in the root zone of barley (Hodeum vulgare L), Italian Ryegrass (Lolium multiflorum Lam), and white clover (Trifolium repens L). Biology and Fertility of Soils 12, 154-160.

Carlsson, G., Huss-Danell, K., 2003. Nitrogen fixation in perennial forage legumes in the field. Plant and Soil 253, 353-372.

De Ruiter, P.C., Van Veen, J.A., Moore, J.C., Brussaard, L., Hunt, H.W., 1993. Calculation of nitrogen mineralization in soil food webs. Plant and Soil 157, 263-273.

De Vos, J.A., Assink, F.B.T., 2004. Nitraatuitspoeling Vredepeel 2002-2003. Plant Research International, Wageningen.

Didden, W.A.M., Marinissen, J.C.Y., Vreeken Buijs, M.J., Burgers, S.L.G.E., Fluiter, R.d., Geurs, M., Brussaard, L., 1994. Soil mesoand macrofauna in two agricultural systems: factors affecting population dynamics and evaluation of their role in carbon and nitrogen dynamics. Agriculture Ecosystems and Environment 51, 171-186.

Donnison, L.M., Griffith, G.S., Hedger, J., Hobbs, P.J., Bardgett, R.D., 2000. Management influences on soil microbial communities and their 
function in botanically diverse haymeadows of northern England and Wales. Soil Biology and Biochemistry 32, 253-263.

Elgersma, A., Hassink, J., 1997. Effects of white clover (Trifolium repens $L$.) on plant and soil nitrogen and soil organic matter in mixtures with perennial ryegrass (Lolium perenne L.). Plant and Soil 197, 177-186.

Elliott, E.T., Heil, J.W., Kelly, E.F., Curtis Monger, H., 1999. Soil structural and other physical properties. In: Robertson, G.P., et al. (Eds.), Standard Soil Methods for Long-Term Ecological Research. Oxford University Press, New York, pp. 74-88.

Evers, M., Postma, R., Van Dijk, T., Vergeer, W., Wierda, C., 2000. Praktijkgids bemesting NMI, Wageningen.

Frey, S.D., Elliott, E.T., Paustian, K., 1999. Bacterial and fungal abundance and biomass in conventional and no-tillage agroecosystems along two climatic gradients. Soil Biology and Biochemistry 31, 573-585.

Frostegard, A., Bååth, E., 1996. The use of phospholipid fatty acid analysis to estimate bacterial and fungal biomass in soil. Biology and Fertility of Soils 22, 59-65.

Fry, J.C., 1990. Direct methods and biomass estimation. In: Grigorova, R., Norris, J.R. (Eds.), Methods in Microbiology, vol. 22. Academic Press, London, pp. 41-85.

Gamper, H., Peter, M., Jansa, J., Luscher, A., Hartwig, U.A., Leuchtmann, A., 2004. Arbuscular mycorrhizal fungi benefit from 7 years of free air $\mathrm{CO}_{2}$ enrichment in well-fertilized grass and legume monocultures. Global Change Biology 10, 189-199.

Ghani, A., Dexter, M., Perrot, K.W., 2003. Hot-water extractable carbon in soils: a sensitive measurement for determining impacts of fertilisation, grazing and cultivation. Soil Biology and Biochemistry 35, 1231-1243.

Grayston, S.J., Griffith, G.S., Mawdsley, J.L., Campbell, C.D., Bardgett, R.D., 2001. Accounting for variability in soil microbial communities of temperate upland grassland ecosystems. Soil Biology and Biochemistry $33,533-551$.

Hassink, J., Bouwman, L.A., Zwart, K.B., Brussaard, L., 1993. Relationships between habitable pore space, soil biota and mineralization rates in grassland soils. Soil Biology and Biochemistry 25, 47-55.

Henriksen, T.M., Breland, T.A., 1999. Nitrogen availability effects on carbon mineralization, fungal and bacterial growth, and enzyme activities during decomposition of wheat straw in soil. Soil Biology and Biochemistry 31, 1121-1134.

Houba, V.J.G., Temminghoff, E.J.M., Gaikhorst, G.A., van Vark, W., 2000. Soil analysis procedures using $0.01 \mathrm{M}$ calcium chloride as extraction reagent. Communications in Soil Science and Plant Analysis 31, 1299-1396.

Jeffries, P., Barea, J.M., 1994. Biogeochemical cycling and arbuscular mycorrhizas in the sustainability of plant-soil systems. In: Gianinazzi, S., Schuepp, H. (Eds.), Impact of Arbuscular Mycorrhizas on Sustainable and Natural Ecosystems. Birkhauser Verlag, Basel, p. 226.

Mäder, P., Edenhofer, S., Boller, T., Wiemken, A., Niggli, U., 2000. Arbuscular mycorrhizae in a long-term field trial comparing low-input (organic, biological) and high-input (conventional) farming systems in a crop rotation. Biology and Fertility of Soils 31, 150-156.

Mawdsley, J.L., Bardgett, R.D., 1997. Continuous defoliation of perennial ryegrass (Lolium perenne) and white clover (Trifolium repens) and associated changes in the composition and activity of the microbial population of an upland grassland soil. Biology and Fertility of Soils 24, 52-58.

Michel, P.H., Bloem, J., 1993. Conversion factors for estimation of cell production rates of soil bacteria from tritiated thymidine and tritiated leucine incorporation. Soil Biology and Biochemistry 25, 943-950.

Neergaard, A.d., Hauggaard-Nielsen, H., Jensen, L.S., Magid, J., 2002. Decomposition of white clover (Trifolium repens) and ryegrass (Lolium perenne) components: $\mathrm{C}$ and $\mathrm{N}$ dynamics simulated with the DAISY soil organic matter submodel. European Journal of Agronomy 16, $43-55$.
Novozamsky, I., Houba, V.J.G., Vaneck, R., Van Vark, W., 1983. A novel digestion technique for multi-element plant analysis. Communications in Soil Science and Plant Analysis 14, 239-248.

Novozamsky, I., Houba, V.J.G., Temminghoff, E., Van der Lee, J.J., 1984. Determination of total $\mathrm{N}$ and total $\mathrm{P}$ in a single soil digest. Netherlands Journal of Agricultural Science 32, 322-324.

Paynel, F., Cliquet, J.B., 2003. N transfer from white clover to perennial ryegrass, via exudation of nitrogenous compounds. Agronomie 23, 503-510.

Pennanen, T., Fritze, H., Vanhala, P., Kiikkila, O., Neuvonen, S., Bååth, E., 1998. Structure of a microbial community in soil after prolonged addition of low levels of simulated acid rain. Applied and Environmental Microbiology 64, 2173-2180.

Prescott, D.M., James, T.W., 1955. Culturing of amoeba proteus on tetrahymena. Experimental Cell Research 8, 256-258.

Ryan, M., Ash, J., 1999. Effects of phosphorus and nitrogen on growth of pasture plants and VAM fungi in SE Australian soils with contrasting fertiliser histories (conventional and biodynamic). Agriculture Ecosystems and Environment 73, 51-62.

Sakamoto, K., Oba, Y., 1994. Effect of fungal to bacterial biomass ratio on the relationship between $\mathrm{CO}_{2}$ evolution and total soil microbial biomass. Biology and Fertility of Soils 17, 39-44.

Schnurer, J., Clarholm, M., Rosswall, T., 1986. Fungi, bacteria and protozoa in soil from 4 arable cropping systems. Biology and Fertility of Soils 2, 119-126.

Schortemeyer, M., Santruckova, H., Sadowsky, M.J., 1997. Relationship between root length density and soil microorganisms in the rhizospheres of white clover and perennial ryegrass. Communications in Soil Science and Plant Analysis 28, 1675-1682.

Schouwenburg, J.C.v., Walinga, I., 1967. The rapid determination of phosphorus in presence of arsenic, silicon and germanium. Analytica Chimica Acta 37, 271-274.

Sissingh, H.A., 1971. Analytical procedure of the Pw method, used for the assessment of the phosphate status of arable soils in the Netherlands. Plant and Soil 24, 483-486.

Smit, A., Zwart, K., Van Kleef, J., 2004. Stikstofstromen op de kernbedrijven Vreedepeel en Meterik. De grondwaterkwaliteit gemeten. Plant Research International, Wageningen.

Smith, S.E., Read, D.J., 1997. Mycorrhizal Symbiosis. Academic Press, San Diego.

Swift, M.J., Heal, O.W., Anderson, J.M., 1979. Decomposition in Terrestrial Ecosystems. Blackwell Scientific Publications, Oxford.

Tobor-Kaplon, M.A., Bloem, J., Romkens, P., de Ruiter, P.C., 2005. Functional stability of microbial communities in contaminated soils. Oikos 111, 119-129.

Van der Wal, A., van Veen, J.A., Smant, W., Boschker, H.T.S., Bloem, J., Kardol, P., van der Putten, W.H., de Boer, W., 2006. Fungal biomass development in a chronosequence of land abandonment. Soil Biology and Biochemistry 38, 51-60.

Veen, J.A.v., Paul, E.A., 1979. Conversion of biovolume measurements of soil organisms, grown under various moisture tensions, to biomass and their nutrient content. Applied and Environmental Microbiology 37, 686-692.

Velvis, H., 1997. Evaluation of the selective respiratory inhibition method for measuring the ratio of fungal: bacterial activity in acid agricultural soils. Biology and Fertility of Soils 25, 354-360.

Vinten, A.J.A., Whitmore, A.P., Bloem, J., Howard, R., Wright, F., 2002. Factors affecting $\mathrm{N}$ immobilisation/mineralisation kinetics for cellulose-, glucose- and straw-amended sandy soils. Biology and Fertility of Soils 36, 190-199.

Wardle, D.A., Lavelle, P., 1997. Linkages between soil biota, plant litter quality and decomposition. In: Cadisch, G., Giller, K.E. (Eds.), Driven by Nature. Plant Litter Quality and Decomposition. CAB International, Wallingford, pp. 107-124.

Yeates, G.W., Bardgett, R.D., Cook, R., Hobbs, P.J., Bowling, P.J., Potter, J.F., 1997. Faunal and microbial diversity in three Welsh grassland soils under conventional and organic management regimes. Journal of Applied Ecology 34, 453-470. 
Zeller, V., Bardgett, R.D., Tappeiner, U., 2001. Site and management effects on soil microbial properties of subalpine meadows: a study of land abandonment along a north-south gradient in the European Alps. Soil Biology and Biochemistry 33, 639-649.

Zelles, L., Rackwitz, R., Bai, Q.Y., Beck, T., Beese, F., 1995. Discrimination of microbial diversity by fatty acid profiles of phospholipids and lipopolysaccharides in differently cultivated soils. Plant and Soil 170, 115-122.
Zhu, Y.G., Laidlaw, A.S., Christie, P., Hammond, M.E.R., 2000. The specificity of arbuscular mycorrhizal fungi in perennial ryegrass-white clover pasture. Agriculture Ecosystems and Environment 77, 211-218.

Zwart, K.B., Burgers, S.L.G.E., Bloem, J., Bouwman, L.A., Brussaard, L., Lebbink, G., Didden, W.A.M., Marinissen, J.C.Y., Vreeken Buijs, M.J., Ruiter, P.C.d., 1994. Population dynamics in the belowground food webs in two different agricultural systems. Agriculture Ecosystems and Environment 51, 187-198. 